\title{
Towards entrepreneurship education: Empowering township members to take ownership of the township economy
}

\begin{tabular}{|c|c|}
\hline $\begin{array}{l}\text { Author: } \\
\text { Semape J. Man }\end{array}$ & yaka-Boshielo ${ }^{1}$ (1) \\
\hline $\begin{array}{l}\text { Affiliation: } \\
{ }^{1} \text { Department } \\
\text { Theology, Fac } \\
\text { and Religion, } \\
\text { Pretoria, Pret } \\
\text { South Africa }\end{array}$ & $\begin{array}{l}\text { f Practical } \\
\text { Alty of Theology } \\
\text { University of } \\
\text { ria, }\end{array}$ \\
\hline $\begin{array}{l}\text { Research Proj } \\
\text { Project Leade } \\
\text { Project Numb }\end{array}$ & $\begin{array}{l}\text { ct Registration: } \\
\text { r: J.A. Meylahn } \\
\text { er: } 02187133\end{array}$ \\
\hline $\begin{array}{l}\text { Description: } \\
\text { Dr Manyaka-B } \\
\text { participating i } \\
\text { project, 'Towa } \\
\text { postfoundatio } \\
\text { public theolog } \\
\text { to the challen } \\
\text { religion in con } \\
\text { Southern Afri } \\
\text { Prof. Dr Johan } \\
\text { Department P } \\
\text { Theology, Fac } \\
\text { and Religion, } \\
\text { Pretoria. }\end{array}$ & $\begin{array}{l}\text { oshielo is } \\
\mathrm{n} \text { the research } \\
\text { rds a practical } \\
\text { nal theology as } \\
\mathrm{y} \text { in response } \\
\text { ges of lived } \\
\text { temporary } \\
\text { a', directed by } \\
\text { n Meylahn, } \\
\text { ractical } \\
\text { ulty of Theology } \\
\text { Jniversity of }\end{array}$ \\
\hline $\begin{array}{l}\text { Correspondin } \\
\text { Semape Many } \\
\text { manyakasp@ }\end{array}$ & $\begin{array}{l}\text { g author: } \\
\text { aka-Boshielo, } \\
\text { smail.com }\end{array}$ \\
\hline $\begin{array}{l}\text { Dates: } \\
\text { Received: } 22 \text { J } \\
\text { Accepted: } 15 \\
\text { Published: } 29\end{array}$ & $\begin{array}{l}\text { une } 2018 \\
\text { lan. } 2019 \\
\text { Apr. } 2019\end{array}$ \\
\hline $\begin{array}{l}\text { How to cite th } \\
\text { Manyaka-Bos } \\
\text { 'Towards entr } \\
\text { education: Em } \\
\text { township mer } \\
\text { ownership of } \\
\text { economy', HT. } \\
\text { Studies/Theol } \\
75(1) \text {, a5166. } \\
\text { 10.4102/hts.v }\end{array}$ & $\begin{array}{l}\text { is article: } \\
\text { hielo, S.J., 2019, } \\
\text { epreneurship } \\
\text { powering } \\
\text { nbers to take } \\
\text { the township } \\
\text { S Teologiese } \\
\text { ogical Studies } \\
\text { https://doi.org/ } \\
75 \text { i1.5166 }\end{array}$ \\
\hline Read online: & \\
\hline 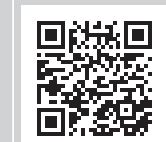 & $\begin{array}{l}\text { Scan this QR } \\
\text { code with your } \\
\text { smart phone or } \\
\text { mobile device } \\
\text { to read online. }\end{array}$ \\
\hline
\end{tabular}

This article explores the role of effective entrepreneurial education in township communities, to address some of the economic challenges facing poor township communities. Effective entrepreneurial education has the potential to ignite economic transformation in township communities. This effective entrepreneurial enterprise should be based on the understanding of whole education principles. This article also explores the role of the social missional entrepreneurial church by applying effective enterprises that would run entrepreneurial activities in township communities. The social missional entrepreneurial church understands that it should approach its mission holistically; 'holistic' here referring to the spiritual, physical, mental, social, emotional and economic spheres. This explorative study aims at understanding how to implement the social missional entrepreneurial enterprises in township communities. It explores effective entrepreneurial programmes that could be an engine in transforming the township communities. It focuses on the definition of education, specifically entrepreneurship education, and how can it be implemented effectively. This entrepreneurship education should resonate with those who live in township communities. It should address the needs and challenges that face township communities. The article will also explore the meaning of the township economy. It will examine the role of Churchpreneur, which refers to the social missional entrepreneurial church in the spotlight, and how this kind of church can be a place where entrepreneurial education is promoted.

Keywords: Education; Entrepreneurial education; Township economy; Missional-entrepreneurial church.

\section{Correctly identified}

According to research carried out by the author (Manyaka-Boshielo 2017a; Manyaka-Boshielo $2017 b$ ), there are many informal economies taking place in townships. An informal economy is defined as 'unregulated by institutions of society, in a legal and social environment where similar activities are regulated' (Charman et al. 2017:1). As reflected upon in the author's other research, the township is full of informal economic activity everywhere. Charman et al. (2016:1) argue that 'the informal economy provides opportunities for employment and entrepreneurship'.

The aim of this article is to reflect on entrepreneurial education that could be effected so the township economy may grow and bring transformation. Entrepreneurship education is expected to give birth to generations of entrepreneurs who are productive and efficient so as to have high competitiveness in the global market (Imorah 2016:291).

This kind of education is holistic; it touches the whole human being. According to Hornby (2007), the Oxford Advanced Learner's Dictionary, education is a process of teaching, training and learning, especially in schools and colleges, to improve knowledge and develop skills. Illeris (2009) puts it this way regarding learning:

Learning aimed at changes not only in what we know but changes in how we know has an opposite rhythm about it and comes closer to etymological meaning of education ('leading out'). 'Informative' learning involves a kind of leading in, or filling of the form. Trans-form-ative learning puts the form itself at risk of change (Not just change but increased capacity). (p. 42)

Herbert Spencer (1820-1903), the leader of a naturalistic movement, argues in his philosophy that the aim of education is preparation for complete living: physical well-being, vocational

Copyright: @ 2019. The Authors. Licensee: AOSIS. This work is licensed under the Creative Commons Attribution License. 
efficiency, parenthood, citizenship and enjoyment (Collier's Encyclopaedia 1963:vol. 8 of 24 volumes, p. 589).

The author is a black South African practical theologian, living in Nellmapius, north-east of Pretoria, who was born into an extremely poor family in Maphotla. Subsequently, his family moved to Moteti in Dennilton in the early years of his life. He does not merely read about poverty in textbooks, but has experienced it. He knows the pain of living as part of the poorest family and community. He knows how it feels to go to school without food, shoes and so on. He understands how it feels to be excluded and marginalised in your own country of origin.

Because of poverty, the author's family failed to enrol him at school; fortunately, in January 1979, he was converted to Christianity (accepted the Lord as his personal saviour), something that transformed his life forever. One of the church members adopted him and sent him to school to do Standard 5; later he began to look for a temporary job to support himself until he completed his studies. He did not like to be a burden on anyone; he wanted to do things that could change his life and future by himself. He believed that as he is created in the image and likeness of God, nothing would be impossible for him. This narrative of God gave him a strong sense of agency inside him. God's narrative had changed his personal narrative.

Today as the author works in ministry, his work involves all pastoral ministry. Through this work, he is exposed to many people who are still living in poverty in Nellmapius Township. As a minister, it came to him that it is not enough to teach the word of God and pray for people; something must be done to help the people to overcome their unfavourable situation, which limits their freedom to become what God intended for them. To achieve this, church services cannot be only on Sundays but must be every day. Hence, the author proposes a missional-social entrepreneurial church, called 'Churchpreneur'. The church should not only be heaven-focused but also Earth-focused. This means it should be relevant to address the daily struggles people endure.

\section{Methodology}

The methodology is generated from secondary data, and the author will also add his personal observations since being actively involved in the township community of Nellmapius.

\section{Entrepreneurship education}

Hindle (2007) defined 'entrepreneurship education' as the transfer of knowledge of how, by whom and with what effects opportunities to create future goods and services are discovered, evaluated and exploited. Education can serve as a preparatory function in relation to a new venture initiation or start-up, whereby the transfer of knowledge and acquisition and development of relevant skills would be expected to increase the self-efficacy and effectiveness of the potential entrepreneur (Gormon, Hanlon \& King 1997:193).
Moreover, they continue by saying entrepreneurship education is a 'preparatory function' for the launch of new ventures, as well as a means to increase self-efficacy. Entrepreneurial education is associated with entrepreneurial self-efficacy, which may increase entrepreneurial intentions (Wilson, Kickul \& Marlimo 2007; Zhao, Seibert \& Hills 2011). 'Self-efficacy' refers to a belief in one's ability to successfully perform the various roles and tasks of entrepreneurship.

Gamede and Uleanya (2017:2) defined entrepreneurship education as the purposeful intervention by an educator in the life of a learner to impact entrepreneurial qualities and skills to enable the learner to survive in the world of business. The culture of entrepreneurship must be established early in the lives of the people living in the township communities. Gamede and Uleanye (2017:1) stated that 'the key to the success of establishing a culture of entrepreneurship in South Africa is education, which depends on all the stakeholders' participation, including state, educators, parents and learners'. The aim of entrepreneurial education, from primary to tertiary, is to transform communities to be productive. Imaroh (2016:288) stated that 'formal education aiming at improving competitive human resources requires links and match with the industrial world'. This simply means that education should be relevant to the conditions of the times.

Erasmus et al. (2006) described entrepreneurial education as a structured, formal conveyance of entrepreneurial competencies, which in turn refers to the concepts, skills and mental awareness used by individuals during the process of starting and developing their growth-orientated business venture. The aim of entrepreneurship education is to raise individuals who are capable of starting new business ventures (Timmons, Eisenman \& O'Conno 2015).

Entrepreneurial education has been defined as 'the skills and knowledge that individuals acquire through investment in schooling, on-the-job training and other types of experience'. Effective entrepreneurial learning as a problem-solving process centres on 'the acquisition, storage and use of entrepreneurial knowledge in long-term memory use' (Rae \& Carswell 2000:221).

Entrepreneurial learning means learning to recognise and act on opportunity, as well as interacting socially to initiate, organise and manage ventures (Rae 2005:324). This helps learners to recognise opportunities as they prevail in their context. It means that instead of seeing problems, they see how to solve those problems.

Opportunity is the ability to see solutions to problems. So when township people, who live with many challenges, undergo entrepreneurial learning, they would be able to identify opportunities in their spaces.

They are not only going to identify but will also know how to exploit those opportunities. This means that recognising 
an opportunity without acting on it or exploiting it is not enough.

Social entrepreneurship education would follow the same patterns of business entrepreneurship. Entrepreneurship education helps improve knowledge and skills of students so that the potential entrepreneurs are well equipped with the essential competencies to enter the business environment (Kiyani 2017:276). What makes the difference between business entrepreneurship and social entrepreneurship is that business entrepreneurship focuses on profit while social entrepreneurship focuses on social impact.

According to his understanding of the preceding description of entrepreneurship education, the author puts it this way: the purpose of entrepreneurship education is to improve knowledge, sharpen skills and encourage behaviour that will help learners be ready to start and run their own businesses. This may be possible by following the correct models and methods of teaching and learning. Thus the following section will highlight different models that could be followed in designing and developing learning materials.

\section{Models of teaching}

There are three models that have been used through the years. They are recorded as follows: supply model, demand model and competence (Bechard \& Gregoire 2005).

The supply model focuses on pedagogical methods highlighting a behaviourist paradigm; this model places the teacher as the one who possesses the knowledge and the student as the one who receives the knowledge from the teacher. The learner is just passive in this paradigm. It is carried out through lectures, reading, watching and listening. In this model, the learner comes to the teacher as an empty vessel, in need of being filled by the teacher.

The demand model 'focuses on pedagogical methods highlighting a subjectivist paradigm involving personalized meaning through participation in terms of exploration, discussion and experimentation' (e.g. library use, interactive searches and simulations). It is better than the first model; at least there is participation.

The competence model focuses on pedagogical methods, highlighting an interactionist theoretical paradigm, in terms of active problem-solving in real-life situations, where teaching is concerned as a strategic intervention to influence how students organise the resources at their disposal (e.g. knowledge and abilities) into competences that can be mobilised for action. This model is the one the author would prefer. Learners are included among those who create knowledge.

Both the demand and competence models fit well within the constructivist approach to entrepreneurship education (Blenker et al. 2012). Constructivism assumes that learning involves active participation of both the learners and teachers in the construction of new understanding.

'Learning' is defined as the process whereby knowledge is created through the transformation of experience. Knowledge results from the combination of grasping and transforming experience (Kolb \& Kolb 2005:193).

Any effective learning must begin with the respective experiences of the learner and the teacher. Learners would be able to easily understand what they are learning because it is connected to their experience. The learner must be able to use his or her experiences to create new knowledge and a new reality. The process of creating this new reality cannot be left to the teacher alone; the learner should play a critical role because the learner is the one who will use the knowledge in his or her environment.

A constructivist learning environment is a learning environment where social interaction, dynamic enquiry and metacognitive reflections are paramount to the student's success (Sultan, Wood \& Koo 2011):

There is no one constructivist theory, but most constructivist theories agree on central ideas: (1) learners are active in constructing their knowledge, and (2) social interactions are important in this knowledge construction process. (Ekpenyong \& Edokpolor 2016:150)

This constructivist approach will be appropriate for township entrepreneurial learning; the people in the township have been surviving in the harshness of exclusion and marginalisation, and they can use their survival skills to create prosperous living.

In simulating entrepreneurial learning as a process of coparticipation, a relationship-based approach that includes arguments, debate and collaboration with others is central (Pittaway \& Cope 2007:213). Learning, therefore, is seen ideally to be a process involving the use and analysis of experiential and theoretical knowledge in various forms of reflection, (re)conceptualisation and action (Pittaway \& Cope 2007:213).

\section{Township economy}

In this article, township economy would refer to any product or services that have been produced, distributed and consumed in township communities (Manyaka-Boshielo 2017a:4). In the 2015 State of the Province address, the Gauteng premier (Makhura 2015:19) stated that township residents must be able to create products and services they use. The township members should be the sole drivers of this township economy.

The author has observed that most township communities belong to stokvels. Malefane and Kok (2017:4) define 'the stokvels as an umbrella term used to describe savings organisations in the African community in South Africa'. Before 1994, the majority of South African people were 
excluded from the mainstream economy. They were unable to own land, which hindered them from building capital and accessing credit (Malefane \& Kok 2017:4). The money in townships rotates through stokvels.

The research company Africa Response (2014) found that $65 \%$ of stokvel savings caters for burials, $30 \%$ goes to savings, $21 \%$ to groceries and only $4 \%$ to investments (Malefane \& Kok 2017:4). The same research company estimated that stokvels' market value is R44 billion, a colossal R2.6bn a year, and that they have a combined membership of over 11.4 million people (Malefane \& Kok 2017:4). The wish and prayer of the author is to see township members becoming part of this promising market.

The author persists in thinking that if these communities can sit down and have powerful conversations, they would be able to start a community bank that would help them to fund their small and medium enterprises. In the township there is a great deal of ongoing informal economic activity. As mentioned previously on the issue of stokvels, there is a lot of money circulating without the required proper regulations. This is not the only informal economy that is happening; many informal businesses exist. The informal economy could be defined as being 'unregulated by the institutions of society, in a legal and social environment where similar activities are regulated' (Castells \& Portes 1989:12; Charman et al. 2017:36).

Research estimates suggest that the country's informal economy provides employment for at least 2.4 million people (13\% of the labour force), in addition to contributing towards the livelihood of 4.4 million unemployed and 14.9 million adults officially described as not economically active (Charman et al. 2017:37).

Indeed, many people in the township support their families through this informal economy, and they are able to create jobs for others. Even though many say these communities are the poorest of the poor, there is nonetheless a great deal of money in these communities. The fact that shopping malls located in these communities include big shops demonstrates that they have observed that there is a good market in the township communities. For example, in Mamelodi, there is Shoprite, Spar, Pick n Pay and so on. They are tapping into this township economy.

This article prefers a constructivist learning theory, as indicated in the previous section. This is a learning method that starts right where people find themselves. People in the township economy have managed to survive the tough times of exclusion and managed in their horrible environment; they can use the same strategy to create knowledge that would be transformative in their communities. There is agency in township communities. This agency can be ignited through entrepreneurial education.

Because the author is a practical theologian, the constructivist learning theory sits well with him. Practical theology starts by listening to the narratives of those who are living in the local context, including listening to the culture and traditions and whole background to the narratives.

\section{The role of big businesses that enter the township}

The author observes that since big corporations entered the township, they have killed the supermarkets that were owned by locals or township businesspeople. Indeed it is totally impossible for local businesspeople to compete with the big corporations that are now operating in the townships. According to black empowerment policies, those who do business in townships must empower the township communities. In this regard, when a mall is built in the township, the owners must make it easy for small businesses to operate in the mall, with reasonable affordable rentals. Big shops such as Pick n Pay must sell shares to the locals who aspire to be in the retail trade so that eventually Pick n Pay might be owned by locals themselves.

\section{Practical theology}

\section{What is practical theology?}

Practical theology takes place when theology tries to answer the concerns of a specific context. Theology will be useless if it cannot work towards solutions of specific contexts. The theology must be socially constructed in a specific context, as we will see in the section on constructivist theory.

Browning argues that different thinkers share one fundamental idea: that practical thinking is the centre of human thinking and that theoretical and technical thinking are abstractions from practical thinking (Browning 1996:8). He continues by saying that theology operates in the same manner; it starts in practice and moves to theory and back to practice.

How can practical theology unearth the context in which it operates? According to Browning (1996), it is to strive to understand the stories of those who are the actors or subjects inside the context. The actors are not acting out of themselves, but there is a background or horizon that influences them to act the way they do. So the fundamentally practical theology is their thirst to understand the context and to try to describe the dominant traditions that are at play. He uses words such as 'foreground', 'background', 'centre' and 'periphery' (Browning 1996:91).

The theology must start with the story of a specific context, which can then move towards historical and systematic theology to bring real transformation. By so doing, it will try to hear from scripture what would be the mind of God concerning the specific situation.

Ballard (1992:29; Manyaka-Boshielo 2017a10) describes the work of practical theology in this way:

The special task of practical theology is to start with the concrete, historical, critically evaluating and enabling practical life of the church in all its forms, drawing on his findings of fundamental, historical and systematic theology. (p. 10) 
The post-foundationalist practical theology approach forces us to listen to the stories from people of their struggles within real situations. Therefore, the post-foundationalist practical theologian pays much attention to the stories of people who face real problems in their specific local context (Manyaka 2015:6; Manyaka-Boshielo 2017a:10; Muller 2011:204).

By understanding the stories from a specific local context and the stories of God, theologians are able to facilitate a better outcome for the people who need help. In this article the author spoke about poverty, which leads to other human brokenness and exclusion. Jesus said to his followers that they should pray and say, ' $[y]$ our kingdom come'. This means that if the kingdom of God prevails here on Earth, the patterns of poverty will be removed, and there will be new patterns of inclusion and wholeness emerging in the township.

\section{The missional-social entrepreneurial church}

As the author stated, it is not enough to do pastoral ministry without touching the lives of people entrepreneurially so that their lives will be transformed permanently. Indeed, the author hates food parcels because they create a sense of dependency. As a practical theologian, the author is convinced that the change people want to see can be facilitated by the church: a missional-social entrepreneurial church. He truly believes that social entrepreneurs are called by God to bring community transformation. Dana (2010) talks about how religions serve the reservoir of wisdom and value towards shaping entrepreneurial activities. In the next section, the author will explore the concept of entrepreneurship, before continuing to explore the missional-social entrepreneurial church.

\section{Entrepreneurship}

In order to understand the missional-social entrepreneurial church, the author wishes to start by defining the concept of entrepreneurship. What is it? The term 'entrepreneurship' connotes 'a special, innate ability to sense and act on opportunity, combining out-of-the-box thinking with a unique brand of determination to create or bring about something new to the world' (Martin \& Osberg 2007:31). It is also important to define the concept of entrepreneur, a term that is derived from the French verb entreprendre, meaning to do something or undertake a project or activity (Manyaka-Boshielo 2017a:2). Schumpeter (1934:78) identified entrepreneurs as 'innovators who carry new combinations', thereby precipitating economic development.

Kiyani (2017:271) argues: 'creation of new opportunities and execution of those opportunities in uncertain and unknown environment is entrepreneurship'. Entrepreneurs can be characterised as individuals who discover and experience business opportunities (Fellnhofer 2017:60).

\section{Social entrepreneurship}

Bacq and Janssen (2011:388) define social entrepreneurship as 'the process of identifying, evaluating and exploiting opportunities aiming at social value creation by means of commercial, market-based activities and the use of a wide range of resources'. Social entrepreneurship aims to serve basic and long-standing needs through innovation, unlike commercial entrepreneurship, which focuses on new needs and profiteering (Cohen \& Peachey 2015:113). Social entrepreneurship is linked with:

... innovative activities and services that are motivated by the goal of meeting a social need and that are predominantly diffused through [existing and newly created] organizations whose primary purposes are social. (Lisetchi \& Brancu 2014:90)

Charles Light defined social entrepreneurship as an effort to bring about sustainable change through pattern-breaking ideas to solve intractable social problems (Mostert 2012:69).

A social entrepreneur is an individual working on his or her own account while primarily pursuing prosocial goals, that is, goals set to benefit people other than the entrepreneur (Stephane, Uhlaner \& Stride 2015:309).

Churchpreneur (the author's term for the missional-social entrepreneurial church) is designed to empower the community through skills of identifying and exploiting opportunities available in the township community. This church does not give people fish but teaches them how to catch the fish. It simply means that the church empowers the community with social entrepreneurial skills. If there is a need for food parcels, they should be provided as a temporary measure for a short period of time. The community should be made aware that they have got potential. Churchpreneur has the ability to communicate within the church and also has a public voice.

The Churchpreneur ignites the potential that lies dormant. The message of salvation is the message of integral human liberation and progress. For this reason, the first task of the church in the city is to help people to better their quality of material as well as their social livelihood (Moloi 2014:5).

Choi (2010:378) puts it this way: Korean churches are involved with business and community development issues directly and indirectly. Some churches and pastors hold formal programmes to inform their members of business opportunities. To take this further, they started a formal and informal organisation that could afford to offer loans to Koreans because the conventional banks were unable to offer Koreans loans.

There is a lesson to be learned by township churches. Over a period of years the author observed that township churches have a dependency mentality that was perhaps created because of the poverty they experienced. Township churches have expectations that white churches must donate to them. The author still remembers, during research conversations, township pastors expressing the expectation of assistance from white research participants. 
Therefore, the township church can learn entrepreneurial activities from the Korean church in New York so that they might be self-sufficient, self-governing and self-supporting. This would only be possible when we become a missionalsocial entrepreneurial church. Fagerli et al. (2012:16) defined a missional church as the essential nature and vocation of the church as called and sent to people. Christian entrepreneurial purpose differs from secular entrepreneurial purpose. Christian purpose is about being obedient to and serving God. The Christian entrepreneur must witness God's goodness, serve others and use business as a vehicle to worship God (Anderson 1999). Entrepreneurial people are called by God to add value to society. So an entrepreneurial church must teach and promote social entrepreneurial activities in the community. Black churches in the UK and other parts of the world were also entrepreneurial; therefore South African township churches must rise to become an entrepreneurial church. Taylor and Chatters in Ayantunji Gbadamosi (2015:6) highlight that black churches are traditionally involved in spearheading a number of programmes geared towards emphasising their significant roles in mediating the broader social environment. The programmes include the following: social, educational and health services for congregants and surrounding communities; economic development initiatives; job training programmes; and a programme for the elderly and their caregivers.

Shumba (2015) stated that:

As part of ensuring that churches encourage business formations and growth, various church organizations have taken deliberate steps to encourage business growth. In this regard the Zimbabwe Assemblies of God Forward in Faith Ministries (ZaogaFIF) which is one of Zimbabwe's largest Pentecostal movement led by Apostle Ezekiel Guti, established a ministry dedicated to business called African Christian Business Fellowship. (p. 155)

He continues saying that, according to the church website (www.faith.ministries.net), a business forum is a ministry dedicated to empowering believers to start, build and consolidate businesses through the application of biblical principles (Shumba 2015:155).

\section{Designing and developing relevant learning materials}

In this section, the author has researched effective learning materials that could be used to empower township communities so that they might take their rightful place in South Africa. Indeed, in order for the township economy to be realised, training must be effected as an empowering tool.

The design and development of learning materials must be informed by the constructivist learning theory. This theory emphasises the active participation of the learners in the process of learning. Past experiences and past knowledge is critically important. The learning must encourage the learners to start with what they know already.
The programme might concentrate on the following: theoretical knowledge, understanding the context of the learners, how to start the business and running of the business.

\section{Conclusion}

The church is being called to work towards social transformation in the township. Social entrepreneurial activities must be promoted through entrepreneurial learning. The doors of the church should be open and strategies sought to train township members for township economic activities.

The pastor, whom the author believes is an entrepreneur, should be the one who leads the church as a social enterprise. He or she must begin to preach about the importance of entrepreneurial activities in the township. The sermons should encourage people to start new businesses. In addition, the sermons preached should be more relevant by addressing current problems that the township communities are facing daily.

The missional-social entrepreneurial church should start with informal ministries such as a business forum, where church members would be encouraged and trained in how to start, run and consolidate a business. This will assist with building a culture of entrepreneurship in the township communities.

A legal business institute can be established to train rounded businesspeople who will lead the communities of the world. This institute should be influenced by biblical principles. By doing this, the church would be in a position to influence the world. The missional-social entrepreneurial church would be a relevant answer to social and economic challenges.

\section{Acknowledgements Competing interests}

The author declares that he has no financial or personal relationships that may have inappropriately influenced him in writing this article.

\section{References}

Anderson, B., 1999, Profile of the Christian entrepreneur, viewed 10 May 2009, from http://www.christianentrepreneurship.org/resources/index.html

Bacq, S. \& Janssen, F, 2011 'The multiple faces of social entrepreneurship. A review regional development', An International Journal 23, 373-403.

Ballard, P., 1992, 'Can theology be practical?', in D. Willows \& J. Swinton (eds.), Spiritual dimension of pastoral care: Practical theology in a multidisciplinary context, pp. 27-35, Jessica Kingley Publishers, Philadelphia, PA.

Bechard, J.P. \& Gregoire, D., 2005, 'Entrepreneurship Education research Revisited The Case of Higher Education', Academy of Management Learning \& Education 4(1), 22-43, http://dx.doi.org/10.5465/AMLE.2005.16132536

Blenker, P., Frederisen, S.H., Korsraad, S., Muller, S. \& Neergaard, H., 2012, 'Entrepreneurship as everyday practice: Towards a personalized pedagogy of enterprise education', Industry and Higher Education 26(6), 417-430. https://doi. org/10.5367/ihe.2012.0126

Browning, D.S., 1996, A fundamental practical theology: Descriptive strategic proposal, Fortress Press, Minneapolis, MN

Charman, J.E., Petersen, L.M., Piper, L.E., Liedeman, R. \& Legg, T., 2017, 'Small area census approach to measure the township informal economy in South Africa', census approach to measure the township informal economy in South Africa',
Journal of Mixed Methods Research 11(1), 36-58. https://doi.org/10.1177/ Journal of Mixed 
Castells, M. \& Portes, A., 1989, 'World underneath: The origins, dynamics and effects of the informal economy', in A. Portes, M. Castells \& L.A. Benton (eds.), The informal economy: Studies in advanced and less developed countries, pp. 11-40, Johns Hopkins University Press, Baltimore, MD.

Cohen, A. \& Peachey, J.A., 2015, 'The making of a social entrepreneurship from participant to cause champion within a sport-for-development context', Sport Management Review 18, 111-125. https://doi.org/10.1016/j.smr.2014.04.002

Choi, H., 2010, 'Institutions and ethnic entrepreneurship: The Korean Church as an incubator of economic', Development Quarterly 24(4), 372-382. https://doi. org/10.1177/0891242410375426

Collier's Encyclopaedia, 1963, Vol. 8 of 24 volumes, The Crowell-Collier Publishing Company, Great Britain.

Dana, L.P., 2010, Entrepreneurship and religion, Edward Elgar, Cheltenham.

Ekpenyong, L.E. \& Edokpolor, J.E., 2016, 'Constructivist approaches: An emerging paradigm for the teaching and learning of business education', Nigeria Journal of Business Education 3(1), 149-159.

Erasmus, B.J., Loedoiff, P.V. Mda, T. \& Nell, P.S., 2006, Management training and development, Oxford University Press, Cape Town.

Fagerli, B., Jorgensen, K., Haug, K.S. \& Tveitereid, K., 2012, A learning missional church Reflections from young missiologists, Regnum Books International, Oxford.

Fellnhofer, K., 2017, 'The power of passion in entrepreneurship education: Entrepreneurial role models encourage passion', Journal of Entrepreneurship Education 20(1), 69-98

Gamede, B.T. \& Uleanya, C., 2017, 'The role of entrepreneurship education in secondary schools at further education and training phase', Academy of Entrepreneurial Journal 23(2), 1-12.

Gbadamosi, A., 2015, Exploring the growing link of ethnic entrepreneurship, markets and pentecostalism in London UK: An empirical study, pp. 150-169, School of Business and Law, University of East London.

Gormon, G., Hanlon, D. \& King, L., 1997, 'Some research perspectives on entrepreneurship education, enterprise education and education for small business management: A ten-year literature review', International Small Business Journal 15(3), 56(22).

Hindle, K., 2007, 'Teaching entrepreneurship at university: From the wrong building to the right philosophy', in A. Fayolle (ed.), Handbook of research I entrepreneurship education, pp. 104-26, Edward Elgar, Cheltenham, UK.

Hornby, A.S., 2007, Oxford advanced learner's dictionary, 7th edn.

Illeris, R., 2009, Contemporary theories of learning: Learning theorists...In their own words, Routledge, London.

Kolb, A.Y. \& Kolb, D.A., 2005, 'Learning styles and learning spaces: Enhancing experiential learning in higher education', Academy of Management Learning \& Education 4(2), 193-212. https://doi.org/10.5465/amle.2005.17268566

Lisetchi, M. \& Brancu, L., 2014, 'The entrepreneurship concept as a social subject of social innovation', Procedi-Social and Behavioral Sciences 124, 89-92. https://doi. org/10.1016/j.sbspro.2014.02.463

Makhura, D., 2015, Gauteng state of the Province address, 23 February 2015, viewed 14 May 2015, from http://www.gautengonline.gov.za/Documents/SOPA $\% 20$ 2015\%20speech\%booklets.pdf

Malefane, L. \& Kok, L., 2017, The savings schemes clubs (Stokvels) in South Africa Lambert Academic Publishing, Johannesburg.

Manyaka, S.J., 2015, 'Social entrepreneurship: A solution for transforming the disadvantaged community of Nellmapius', HTS Teologiese Studies/Theological Studies 71(3), 7. https://doi.org/10.4102/hts.v71i3.2821
Manyaka-Boshielo, S.J., 2017a, 'Social entrepreneurship as a way of developing sustainable township economies', HTS Teologiese studies/Theological Studies 74(4), a3830. https://doi.org/10.4102/hts.v73i3830

Manyaka-Boshielo, S.J., 2017b, 'Exploring possibilities of social entrepreneurial activities as a tool to reduce unemployment amongst churches in Tshwane central and Mamelodi East: Pretoria case study', HTS Teologiese Studies/Theological Studies 73(3), a4707. https://doi.org/10.4102/hts.v73i4706

Martin, R.L. \& Osberg, S., 2007, 'Social entrepreneurship: The case for definition' Stanford Social Innovation Review, 29-39.

Moloi, V., 2014, 'Living in townships: An appraisal of Pentecostal social ministry in Tshwane', HTS Teoloiese Studies/Theological Studies 70(3), art 2791, 1-9. https:// doi.org/10.4102/hts.v70i3.2791

Mostert, J., 2012, 'Community psychology as socio-missional entrepreneurship', Journal of Psychology and Christianity 31(1), 66-70.

Muller, J.C., 2011, 'Postfoundational practical theology for a time of transition', HTS Teologiese Studies/Theological Studies 67(1), Art 837, 1-5.

Pittaway, L. \& Cope, J., 2007, 'Simulating entrepreneurial learning: Integrating entrepreneurial learning', Approach to learning. Management Learning 38(2), 211-233. https://doi.org/10.1177/1350507607075776

Rae, D., 2005, 'Entrepreneurial learning: A narrative-based conceptual model', Journal of Small Business and Enterprise Development 12(3), 323-335. https://doi. org/10.1108/14626000510612259

Rae, D. \& Carswell, M.,2000, 'Using a life-story approach in researching entrepreneurial learning: The development of a conceptual model and its implications in the design of learning experiences', Education and Learning 42(4/5), 220-228. https://doi.org/10.1108/00400910010373660

Kiyani, S.A., 2017, 'Role of entrepreneurship education on student attitudes', Abasyn of Social Sciences 10(2), 270-293.

Schumpeter, J.A., 1934, Theory of economic development, 2nd edn., Harvard University Press, Cambridge, MA.

Shumba, V., 2015, 'The role of Christian churches in entrepreneurial stimulation', The International Journal of Business and Management 3(7), 152-157.

Stephane, U.T.E., Uhlaner, L.M. \& Stride, C., 2015, 'Institutions and socia entrepreneurship: The role of institutional voids, institutional support, and institutional configurations', Journal of International Studies 46, 308-331.

Sultan, W.H., Wood, P.C. \& Koo, A.C., 2011, 'A constructivist approach for digital learning: Malaysian schools case study', Educational Technology \& Society $14(4)$ 149-163.

Timmons, H.N.J.A., Eisenman, E. \& O'Connor, A., 2015, Entrepreneurship education: A global consideration from practice to policy around the world, Executive summary of the 2015 wise research report, Qatar Foundation, Qatar.

Imaroh, T.S., 2016, 'Entrepreneurship education as a strategy for improving the economical independence and competitive ability of society in Asean economic community (AEC) ERA', International Journal of Organizational Innovation 9(2), 287-294, viewed 06 November 2018, from http//www.ijoionline.org/

Wilson, F., Kickul, J. \& Marlimo, D., 2007, 'Gender entrepreneurial self-efficacy, and entrepreneurial career intentions: Implication for entrepreneurship education' Entrepreneurship, Theory and Practice 31(3), 387-406. https://doi.org/10.1111/ j.1540-6520.2007.00179.x

Zhao, H., Seibert, S.E. \& Hills, G.E., 2005, 'The mediating role of self-efficacy in the development entrepreneurial intentions', The Journal of Applied Psychology 90(6), 1265-1272. https://doi.org/10.1037/0021-9010.90.6.1265 